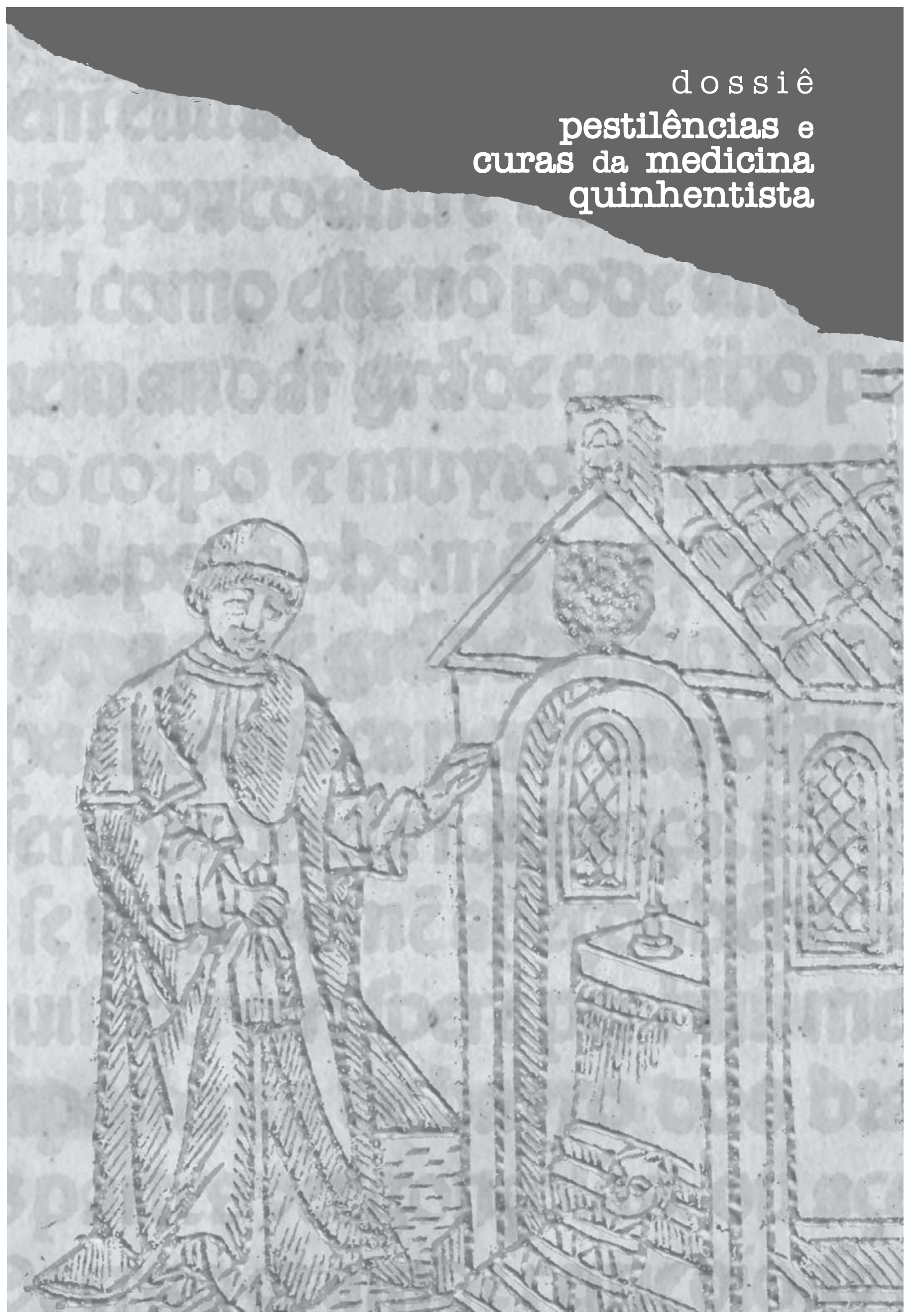




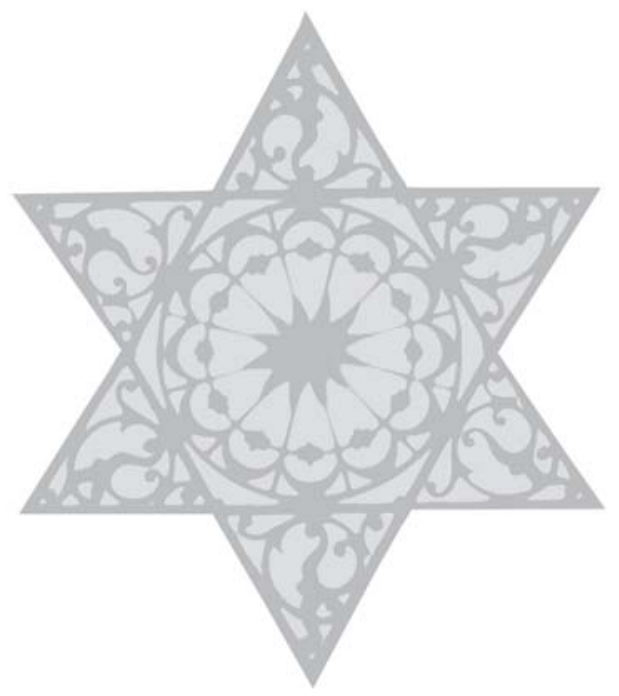




\title{
Em torno de dois textos médicos antigos
}

\section{On two antique medical texts}

\author{
Maria Carlota Rosa \\ Professora do Programa de Pós-graduação em Lingüística e do Departamento de \\ Lingüística e Filologia da Faculdade de Letras da Universidade Federal do Rio de Janeiro \\ Cidade Universitária - Ilha do Fundão \\ 21941-590 Rio de Janeiro - RJ Brasil \\ carlota@ufrj.br
}

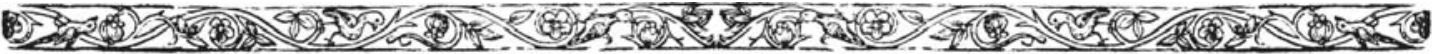

ROSA, M. C. Em torno de dois textos médicos antigos

História, Ciências, Saúde-Manguinhos, v. 12, n. 3, p. 771-74, set.-dez. 2005.

Os textos aqui reunidos - Regimento proueytoso contra ha pestenença e Modus curandi cum balsamo - constituíam, por volta de 1530, a biblioteca médica conhecida em Portugal, posta em letras góticas por impressores estrangeiros: o alemão Valentim Fernandes, talvez o mais importante impressor do período, que trabalhou em Lisboa entre 1495 e 1518, e Germão Galharde, francês que exerceu seu ofício em Lisboa e Coimbra entre 1519 e 1560 . O modus curandi, de que se passa a ter notícia em 1974, graças ao bibliófilo José de Pina Martins, é obra anônima. Atribui-se a Johannes Jacobi a autoria do Regimento proueytoso, que teve versões em latim, francês e inglês. Ambos os textos são apresentados em fac-símile e em português atual, reproduzindo-se o primeiro em português arcaico mas com caracteres tipográficos modernos. Complementa esta incursão filológica pela medicina quinhentista um erudito glossário de grande valia como ferramenta para a interpretação não só do Regimento proueytoso como de outros textos da época. Dois artigos colocam em perspectiva histórica os documentos aqui reproduzidos.

PALAVRAS-CHAVE: Regimento proueytoso contra ha pestenença; Modus curandi cum balsamo; Jacobi-Kaminto; João Curvo Semedo; Luiz Gomes Ferreyra; John Huxham; tratados sobre a peste; Portugal me dieval; origens da imprensa em Portugal; Valentim Fernandes; Germão Galharde.

ROSA, M. C. On two antique medical texts.

História, Ciências, Saúde - Manguinhos, v. 12, n. 3, p. 771-74, set.-dez. 2005.

The two texts presented here-Regimento proueytoso contra ha pestenença [literally, "useful regime against pestilence"] and Modus curandi cum balsamo ["curing method using balm"] - represent the extent of Portugal's known medical library until circa 1530, produced in gothic letters by foreign printers: Germany's Valentim Fernandes, perhaps the era's most important printer, who worked in Lisbon between 1495 and 1518, and Germão Galharde, a Frenchman who practiced his trade in Lisbon and Coimbra between 1519 and 1560. Modus curandi, which came to light in 1974 thanks to bibliophile Jose de Pina Martins, is anonymous. Johannes Jacobi is believed to be the author of Regimento proueytoso, which was translated into Latin (Regimen contra pestilentiam), French, and English. Both texts are presented here in facsimile and in modern Portuguese, while the first has also been reproduced in archaic Portuguese using modern typographical characters. This philological venture into sixteenth-century medicine is supplemented by a scholarly glossary which serves as a valuable tool in interpreting not only Regimento proueytoso but also other texts from the era. Two articles place these documents in historical perspective.

KEYWORDS: Regimento proueytoso contra ha pestenença, Regimen contra pestilentiam, Modus curandi cum balsamo, Jacobi-Kaminto, João Curvo Semedo, Luiz Gomes Ferreyra, John Huxham, treatises on the plague, medieval Portugal, origins of the printing press in Portugal, Valentim Fernandes, Germão Galharde. 
$\mathrm{E}$ mbora em línguas diferentes, com temáticas diferentes, os textos aqui reunidos - 0 Regimento proueytoso contra ha pestenença e o Modus curandi cum balsamo - representam o que constituiria, até cerca de 1530, a biblioteca médica conhecida, impressa em Portugal. Nenhuma das obras está datada: a época de impressão tem sido postulada não somente com base nas características materiais dos exemplares, como ainda em dados indiretos.

Ambos os textos são representativos do início da imprensa em Portugal, quando os impressores são estrangeiros e o gótico, a letra negra, é o tipo empregado. O Regimento proueytoso contra ha pestenença foi impresso pelo alemão Valentim Fernandes, talvez o mais importante impressor do período em Portugal, que trabalhou em Lisboa entre 1495 e 1518. Germão Galharde, impressor do Modus curandi cum balsamo, era francês e exerceu sua atividade em Lisboa e em Coimbra entre 1519 e 1560 (Norton, 1978, p. 500-1). A semelhança entre os tipos em ambas as obras deve-se ao fato de Galharde ter adquirido o material tipográfico da oficina de Fernandes (e não só: também das oficinas de João Pedro Bonhomini de Cremona e de Hermão de Campos - Norton, 1978, p. 500).

O modus curandi, de que se passa a ter notícia em 1974, através de artigo do bibliófilo José de Pina Martins, é obra anônima, da qual não se conhece tradução portuguesa. Por seu turno, a autoria do Regimento proueytoso, obra que conheceu muitas versões em latim, também traduzida para o francês e para o inglês, foi amplamente investigada, especialmente por Mário da Costa Roque (1979). A partir da obra de Roque, considera-se seu autor Johannes Jacobi, tradução latina de Jehan Jasme (ou Jacme, Jacou, Jame, Jaume, português antigo Jemes, atualmente Jaime), médico que teria vivido em Montpellier em meados do século XIV. D. Raminto (ou Ramitte, Canuto, Kanutus, Kaminti, Kamitus, Kamiutus, Kanunti), citado no texto português, teria estabelecido um "texto sincrético" (Roque, 1979, p. 302), acrescentando alguns elementos ao texto de Jacobi e omitindo outros. De Frei Luiz de Rás sabe-se que foi catedrático de Filosofia Natural na Universidade de Lisboa e lente de Véspera de Teologia na mesma Universidade. Supõe-se ter morrido em 1520 ou 1521, uma vez que foi substituído na cadeira de Filosofia Natural em 24 de janeiro de 1520 e ter sido essa cadeira posta em concurso em 16 de fevereiro de 1521 (Roque, 1979, p. 309). Tornou-se Ministro Provincial da Seráfica Ordem dos Claustrais muito possivelmente em 1500 (Roque, 1979, p. 305ss), título que não é enunciado no Regimento, o que se constituiu num dos argumentos levantados para propor a impressão da obra ainda no século XV.

Ambos os textos são apresentados em fac-símile e em edições que transcrevem esses cimélios em caracteres tipográficos modernos. Ambos são, também, traduzidos, dando a este verbo o significado do antigo tralladar: no caso do Regimento, apresenta-se uma versão do texto no português atual; para o Modus curandi, apresenta-se uma tradução do latim para o português. Para o texto em português, um glossário serve de auxiliar na tradução intra-língua.

Em seguida aos textos, O regimento contra a pestilência e a receita do bálsamo-alguns comentários à luz da 'medicina científica' focaliza o discurso médico nas duas obras, postas em contraponto com obras do século XVIII, que davam início à chamada medicina científica.

O impresso em português é retomado em Regimento proveitoso contra a pestilência (c. 1496) - uma apresentação, para um estudo do contexto médico da época. 
$\mathrm{W}$ ritten in different languages and focusing on different matters, the Regimento prouey toso contra ha pestenença and Modus curandi cum balsamo represent the totality of the known medical library printed in Portugal until circa 1530. These texts are undated, and the year of their printing is inferred from their physical characteristics and from historical facts.

Both texts are representative of the origins of printing in Portugal, when printers were foreigners, and all the types of the period were gothic. The Regimento proueytoso contra ha pestenença was printed by the German printer Valentim Fernandes, at that time probably Portugal's most important printer, in activity in Lisbon from 1495 to 1518. Germão Galharde published the Modus curandi cum balsamo. He was French, and had printing presses in Lisbon and in Coimbra from 1519 to 1560 (Norton, 1978, pp. 500-1). The types in both books are similar since Galharde had purchased types and ornamental material from Fernandes (and also from João Pedro Bonhomini de Cremona and from Hermão de Campos - Norton, 1978, p. 500).

The Modus curandi is anonymous. It was unknown until 1974, when José de Pina Martins published a note on it.

The Regimento proueytoso had many editions in Latin and French; there were also English editions. Many researchers have studied it, especially Mário da Costa Roque (1979). From Roque's 1979 book onward, the Regimento proueytoso has been attributed to Johannes Jacobi, with its translation into Latin ascribed to Jean Jasme (or Jacme, Jacou, Jame, Jaume, old Portuguese Jemes, now Jaime), a doctor who lived in Montpellier in the fourteenth century. Raminto (or Ramitte, Canuto, Kanutus, Kamitus, Kamiutus, Kanunti), mentioned in the Portuguese version, is said to have established a "syncretic text" (Roque, 1979, p. 302), adding some parts to Jacobi's work and suppressing others. Friar Luiz de Rás, the translator, occupied the Chair of Natural Philosophy at the University of Lisbon and was lecturer of Theology at the same university. Since he was substituted on January 24, 1520, in the Chair of Natural Philosophy, and since the Chair was vacant in February 1521, Rás probably died in late 1520 or early 1521.

Both texts have been reproduced in facsimile and in modern typographic characters. Translations are provided of both texts, using "translation" in the loose sense of the term. Regimento has been translated into modern Portuguese; Modus curandi has been translated from Latin into Portuguese. A glossary to the Regimento is provided as a reading aid.

"Regime for treating the plague and the prescription of balm: some comments from the perspective of 'modern medicine'" provides an analysis of medical discourse in both texts and compares them to medical works from the beginning of so-called scientific medicine, in the eighteenth century.

"Useful regime against the plague (ca. 1496) - an introduction" analyzes the Portuguese historical context of these medical writings. 


\section{REFERÊNCIAS BIBLIOGRÁFICAS/REFERENCES}

Norton, F. J.

1978

Roque, Mário da Costa 1979
A descriptive catalogue of printing in Spain and Portugal, 1501-1520. Cambridge (UK): Cambridge University Press.

As pestes medievais europeias e o "Regimento proueytoso contra ha pestenença", Lisboa, Valentim Fernandes (1495-1496): tentativa de interpretação à luz dos conhecimentos pestológicos actuais. Paris: Fundação Calouste Gulbenkian/Centro Cultural Português. 